\author{
MAREK CAŁA*, ANTONI TAJDUŚ*, WACŁAW ANDRUSIKIEWICZ*, \\ MICHAŁ KOWALSKI*, MALWINA KOLANO*, AGNIESZKA STOPKOWICZ*, \\ KATARZYNA CYRAN*\#, JOANNA JAKÓBCZYK*
}

\title{
LONG TERM ANALYSIS OF DEFORMATIONS IN SALT MINES: KLODAWA SALT MINE CASE STUDY, CENTRAL POLAND
}

\section{DLUGOTERMINOWA ANALIZA DEFORMACJI W KOPALNIACH SOLI: KOPALNIA SOLI KLODAWA, CENTRALNA POLSKA}

\begin{abstract}
Located in central Poland, the Kłodawa salt dome is $26 \mathrm{~km}$ long and about $2 \mathrm{~km}$ wide. Exploitation of the dome started in 1956, currently rock salt extraction is carried out in 7 mining fields and the 12 mining levels at the depth from 322 to 625 meters below sea level (m.b.s.l.). It is planned to maintain the mining activity till 2052 and extend rock salt extraction to deeper levels. The dome is characterised by complex geological structure resulted from halokinetic and tectonic processes.

Projection of the 3D numerical analysis took into account the following factors: mine working distribution within the Kłodawa mine (about 1000 rooms, $350 \mathrm{~km}$ of galleries), complex geological structure of the salt dome, complicated structure and geometry of mine workings and distinction in rocks mechanical properties e.g. rock salt and anhydrite. Analysis of past mine workings deformation and prediction of future rock mass behaviour was divided into four stages: building of the $3 \mathrm{D}$ model (state of mine workings in year 2014), model extension of the future mine workings planned for extraction in years 2015-2052, the 3D model calibration and stability analysis of all mine workings.

The 3D numerical model of Kłodawa salt mine included extracted and planned mine workings in 7 mining fields and 14 mining levels (about 2000 mine workings). The dimensions of the model were $4200 \mathrm{~m} \times 4700 \mathrm{~m} \times 1200 \mathrm{~m}$ what was simulated by 33 million elements. The 3D model was calibrated on the grounds of convergence measurements and laboratory tests. Stability assessment of mine workings was based on analysis of the strength/stress ratio and vertical stress. The strength/stress ratio analysis enabled to indicate endangered area in mine workings and can be defined as the factor of safety. Mine workings in state close to collapse are indicated by the strength/stress ratio equals 1 . Analysis of the vertical stress in mine workings produced the estimation of current state of stress in comparison to initial (pre-mining) conditions.

The long-term deformation analysis of the Kłodawa salt mine for year 2014 revealed that stability conditions were fulfilled. Local disturbances indicated in the numerical analysis were connected with high chambers included in the mining field no 1 and complex geological structure in the vicinity of mine workings located in the mining fields no 2 and 3. Moreover, numerical simulations that projected the future extraction progress (till year 2052) showed positive performance. Local weakness zones in the mining
\end{abstract}

* AGH UNIVERSITY OF SCIENCE AND TECHNOLOGY, FACULTY OF MINING AND GEOENGINEERING, AL. A. MICKIEWICZA 30, 30-059 KRAKÓW, POLAND

\# Corresponding author: kcyran@agh.edu.pl 
field no 7 are associated with occurrence of carnallite layers and intensive mining which are planned in the mining field no 6 at the end of rock salt extraction.

Keywords: deformation analysis, Kłodawa salt dome, 3D numerical analysis, stability conditions

Wydobycie soli kamiennej w Kopalni Soli Kłodawa prowadzone jest obecnie w 7 polach eksploatacyjnych na 12 poziomach kopalniach (głębokość 322 - 625 m p.p.m.). Planowane przedłużenie eksploatacji do roku 2052, wiąże się z udostępnieniem zasobów na kolejnych (niższych) poziomach kopalnianych. Kopalnia Soli Kłodawa eksploatuje sól kamienną w wysadzie solnym, który charakteryzuje się skomplikowaną budową geologiczną.

W modelu numerycznym Kopalni Soli Kłodawa odwzorowano przestrzenny układ wyrobisk kopalnianych (około 1000 komór i 350 km wyrobisk chodnikowych), złożoną geometrię wyrobisk, skomplikowaną budowę geologiczną wysadu oraz uwzględniono zróżnicowanie własności mechanicznych skał. Analizę numeryczną deformacji wyrobisk kopalnianych (dotychczas wybranych i planowanych do wybrania) podzielono na 4 etapy, które obejmowały: budowę modelu 3D kopalni (za bazowy przyjęto stan wyrobisk w roku 2014), rozszerzenie modelu o wyrobiska planowane do wykonania w latach 2015-2052, kalibrację modelu 3D, analizę stateczności. Model numeryczny 3D obejmował wycinek górotworu o wymiarach $4200 \mathrm{~m} \times 4700 \mathrm{~m} \times 1200 \mathrm{~m}$. Model buduje około 33 miliony elementów. Kalibrację modelu wykonano na podstawie pomiarów konwergencji (prowadzonych w kopalni) oraz wyników testów laboratoryjnych skał budujących złoże. Ocenę stateczności wyrobisk kopalnianych przedstawiono na podstawie analizy stanu wytężenia oraz analizy stanu naprężenia w górotworze.

Wyniki przeprowadzonej analizy numerycznej wykazały, że warunek stateczności wyrobisk Kopalni Soli Kłodawa jest spełniony dla stanu na rok 2014. Lokalnie występujące strefy wytężenia związane są z wysokimi komorami w polu eksploatacyjnym nr 1 oraz złożoną budową geologiczną w otoczeniu wyrobisk zlokalizowanych w polach eksploatacyjnych nr 2 i 3. Prognoza dla projektowanego stanu wyrobisk w roku 2052 (zakończenie eksploatacji) wykazała pozytywne rezultaty. Lokalne strefy osłabienia, które zidentyfikowano w polu eksploatacyjnym $\mathrm{nr}$ 7, związane są z występowaniem warstw karnalitu oraz intensywnymi pracami górniczymi, które w ostatniej fazie eksploatacji będą skoncentrowane w polu eksploatacyjnym $\mathrm{nr} 6$.

Słowa kluczowe: analiza deformacji, wysad solny Kłodawa, analiza numeryczna 3D, warunki stateczności

\section{Introduction}

The long-term mining plans and maintenance of extracted mine workings are bound by a necessity to ensure their stability. Estimation and prediction of stability conditions in mine workings require consideration of the following factors: geological structure, the geometry and distribution of the underground mine workings, mechanical properties of the local rocks, changes in stress caused by mining and the influence of the neighbouring mining openings. Numerical methods as advanced tools are used for studying and projecting complex conditions as well as modelling of rocks behaviour (Mortazavi et al., 2009; Jing, 2003; Jing \& Hudson, 2002). Moreover, the geomechanical modelling of salt domes includes the idealisation of geological structure, the selection of appropriate mathematical models and parameters (Heusermann et al., 2012). Furthermore, forecasting of mine stability conditions in salt rocks mass requires addressing problems connected with rheological properties of salt, the impact of time to salt geomechanical properties and mine workings deformations (D’Obyrn \& Hydzik Wiśniewska, 2013).

The Kłodawa salt mine is the largest active mining plant in Poland where salt is extracted in room and pillar system. Currently, the exploitation is carried out in seven mining fields and at 
twelve mining levels. Over 50 years of rock salt extraction resulted in complicated structure and geometry of mine workings. In addition, the inner structure of Kłodawa salt dome is complex due to tectonic and halokinetic processes. Future plans of Kłodawa salt mine are aimed to continue salt extraction (till 2052) and extend mining to deeper levels. Long term deformation analysis presented in this paper was intended to assess the current and future stability conditions of the whole mine. The analysis includes planned extension of exploitation and its impact to stability conditions of all extracted and planned mine workings.

\section{History of Kłodawa Salt Mine exploitation}

The Kłodawa salt deposit was discovered by geophysical and drilling methods between 1946 and 1949. Mine was opened by two shafts in 1951-1952. Three years later the salt dome was cut by the mining level 450 (Chwałek, 2010). Initially, the mine was designed to potassiummagnesium $(\mathrm{K}-\mathrm{Mg})$ salts extraction. However, intensive exploration works and salt resources evaluation led to decision about rock salt exploitation. Consequently, production and extraction of rock salt started in 1956. During next few years (1960-1967) two lower mining levels 525 and 600 were sinking. Moreover, the ventilation shaft was put into use in 1968. Further development of the Kłodawa salt mine fell in 1970s and 1980s when the next mining levels cut the salt deposit (Chwałek, 2010). Currently, there are 7 mining fields and 12 mining levels (450, 475, 500, 525, $550,575,600,630,660,690,720$, and 750 ) at the depth from 322 to 625 m.b.s.l. It is planned to maintain mining till 2052 and develop of rock salt extraction at deeper levels in all mining fields. In the mining field no 2, 3, 5 and 7 exploitation is intended to reach depth of 657-698 m.b.s.l. (mining levels 780 and 820). Cutting works at the mining level 780 has been started in year 2014 .

The rock salt in the Kłodawa mine is extracted by the room and pillar system characterised by modules that consist of room and pillars. Dimensions of the typical module (module 1) are: width of $30 \mathrm{~m}$ and height of $30 \mathrm{~m}$. The size of room in the module is $15 \mathrm{~m}$ wide and $15 \mathrm{~m} \mathrm{high}$, the length is limited by the salt doom size and stability conditions. The module includes also inter-room pillar $15 \mathrm{~m}$ wide and inter-level pillar $15 \mathrm{~m}$ thick. In the mining field no 1 described dimensions of the module is applied below the mining level 600. At upper mining levels the module (module 2) of $30 \mathrm{~m}$ wide and $25 \mathrm{~m}$ high (with the same dimensions of the room) is used. This type of module was characteristic for the first years of rock salt extraction (Andrusikiewicz \& Poborska-Młynarska, 2012). However, dimensions of room and pillars in the module are differentiated concerning the mining field and mining level. For instance, in mining field no 7 , mine workings planned to extraction after 2015 include rooms $12 \mathrm{~m}$ wide and $12 \mathrm{~m}$ high, $18 \mathrm{~m}$ wide inter-room pillars and $18 \mathrm{~m}$ thick inter-level pillar.

\section{Outline of the Kłodawa salt dome geology}

The Kłodawa salt dome is located in Kujawy region (Central Poland). The region is characterised by the most complete lithostratigraphic profile (Fig. 1A) and maximum thickness of Zechstein salt-bearing formation (Dadlez et al., 1995; Dadlez, 2003; Krzywiec, 2004, 2006; Toboła, 2016).

The Kłodawa salt dome (Fig. 1B) is part of the Izbica Kujawska-Łęczyca salt ridge which is the largest salt structure in Poland (Tarka, 1992; Burliga et al., 1995; Burliga, 2014). The salt 
dome is about $26 \mathrm{~km}$ long and about from 0.5 to $2 \mathrm{~km}$ wide and elongated in NW-SE direction. The shape of the dome is asymmetrical: NE side dips moderately $\left(55-70^{\circ}\right)$ at NE but the SW side dips almost vertically (Dadlez \& Marek 1974; Poborski, 1971). The dome rises from the depth of $7-8 \mathrm{~km}$ and it is surrounded by deformed Mesozoic (Triassic-Jurassic) and partly Tertiary strata as well as covered by Quaternary and Tertiary sediments. The salt mirror was found at the depth of 100-350 m under the surface. The Zechstein salt series is represented by rock salt, $\mathrm{K}-\mathrm{Mg}$ salts and intercalations of anhydrite, dolomite and shales. There are three fully developed cyclothems (PZ2-PZ4) with rock salt. The lowermost Zechstein cyclothem PZ1 is known only as tectonically transported blocks. The K-Mg salts, mainly carnallite occur in cyclothems PZ2, PZ3 and PZ4. The salt layers are covered by the gypsum-anhydritic-clay cap from the dissolution of the rock salt (residuum) and its thickness is from few to max. $250 \mathrm{~m}$ (Werner et al., 1960; Burliga 2006, 2014; Burliga \& Misiek, 1997; Toboła, 2016). Upward movement of salt and the structural evolution of the dome started in Triassic and continued till Tertiary (Krzywiec, 2004). The internal structure of the dome is complicated as a result of deformations and different mechanical properties of rocks (Burliga, 2006, 2014; Burliga \& Misiek, 1997; Tarka, 1992).

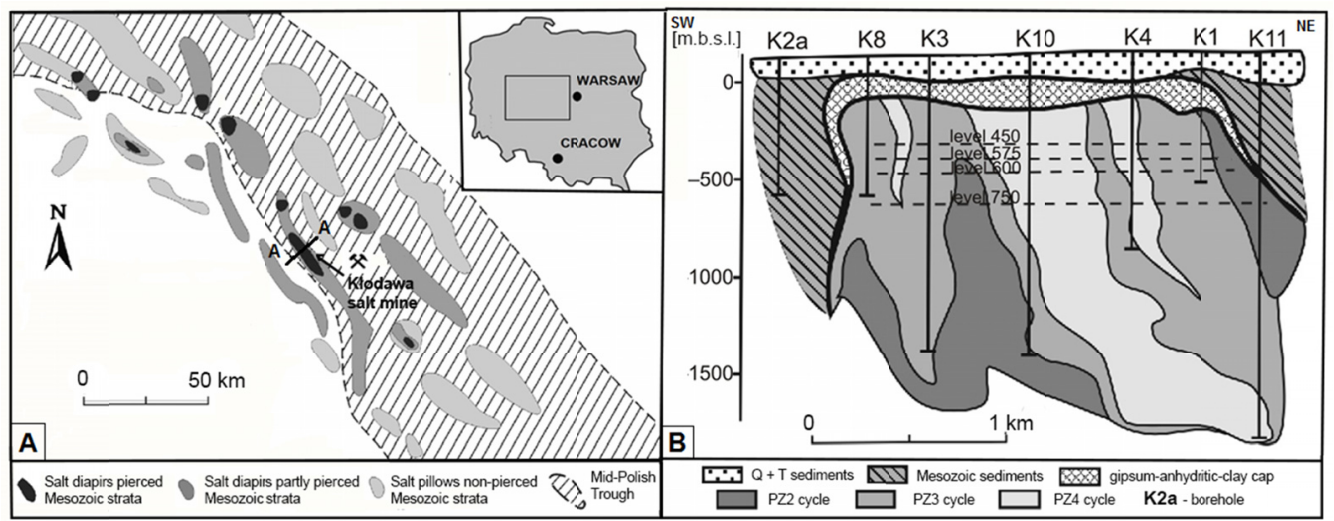

Fig. 1. A - Location of the Kłodawa salt mine against the background of other Zechstein salt structures (after Garlicki \& Szybist, 1986). B - Geological cross-section (A-A) through the Kłodawa salt dome (after Szybist, 1995; Burliga et al., 1995; Toboła, 2016 simplified)

The mining fields are located in the central part of the diapir and comprise area about $8 \mathrm{~km}$ long (according to strike direction) and $2 \mathrm{~km}$ wide (Fig. 1B). Mine workings cut the uppermost part of the Kłodawa salt dome and as a result the inner structure of the dome was recognized. The main effect of salt halokinetic movement is piercing the older lithostratigraphical units with younger ones as well as the presence of high-amplitude folds. Character and style of deformations change throughout the Kłodawa dome. Deformations are less intensive in the north-western part. The geological structure in the central and north-eastern part of the dome is more complex. Observations from mine galleries showed extremely complex internal deformations such as asymmetric folds, boudins, small-scale faults, veins and repetitions of the same lithostratigraphical units (Burliga, 1996, 2006, 2014; Tarka, 1992). 


\section{Deformation analysis}

Long term deformation analysis of rock mass assumed stability estimation of 12 mining levels and 7 mining fields (till 2014) as well as prediction for mine workings planned to extraction after 2014 including the deepest mining levels 780 and 810. Deformation analysis in the Kłodawa salt mine was based on the 3D numerical modelling. The numerical model simplifies in an acceptable extent the actual salt deposit and mining situation as well as differentiates the rock mechanical behaviour. 3D finite difference program (FLAC3D, Itasca Consulting Group) was used to project the mechanical behaviour of salt and nonsalt rocks in order to evaluate stability conditions of the mine. FLAC modelling techniques are useful in prediction and monitoring of caverns and rooms stability in salt mines because the programme can simulate the behaviour of materials that exhibit creep (Zhang et al., 2015; Swift \& Reddish, 2005; Cała et al., 2016).

Projection of the 3D numerical analysis took into account the following factors: mine working distribution within the Kłodawa mine (about 1000 rooms, $350 \mathrm{~km}$ of galleries), complex geological structure of the salt dome and each mining level as well as distinction in rocks mechanical properties e.g. rock salt and anhydrite.

Analysis of past mine workings deformation and prediction of future rock mass behaviour was divided into four stages: building of the 3D model (state of mine workings in year 2014), model extension of the future mine workings planned for extraction in years 2015-2052, 3D model calibration and stability analysis of all mine workings.

The 3D model of the Kłodawa salt mine was built based on mining levels maps reflecting past distribution of mine workings and stages of mine development as well as geological crosssections (Fig. 2). The dimensions of the model in shape of cuboid are: length $4200 \mathrm{~m}$, width $4700 \mathrm{~m}$ and height $1200 \mathrm{~m}$. The model extended vertically from the ground surface to a depth below the lowermost mining level. Extracted and planned mine workings at mining levels from 450 to 810 in 7 mining fields were projected in the 3D model. As a result, the mesh contains about 33 million tetrahedral elements. The dimensions of the elements in the model centre were smaller (about $4 \mathrm{~m}$ ) and bigger at the edges of the model (about $100 \mathrm{~m}$ ).

The initial calibration of the 3D model was based on convergence measurement. In the Kłodawa mine convergence of mine working has been monitoring since 1980s. The measurement network was developed with exploitation progress. Usually the interval change were measured between roof-floor and both walls in selected chambers. Consequently, the monitoring periods were differentiated from 5 to 30 years, depending on mining field, level or even room.

Stability assessment of mine workings for all 7 mining fields and 14 mining levels was based on analysis of strength/stress ratio and vertical stress. The strength/stress ratio analysis enabled to indicate endangered area in mine workings and can be defined as the factor of safety. Mine workings in state close to collapse are indicated by the strength/stress ratio equals 1 . Analysis of the vertical stress in mine workings gave current state of stress in comparison to initial (premining) conditions.

In order to project and model mechanical behaviour of the rock mass in the 3D model four layers were distinguished: rock salt, carnallite, anhydrite and other rocks e.g. dolomite or shales. Mechanical properties of these layers were determined on the basis of laboratory tests. The mechanical parameters of the layers applied to numerical analysis are presented in Table 1. 


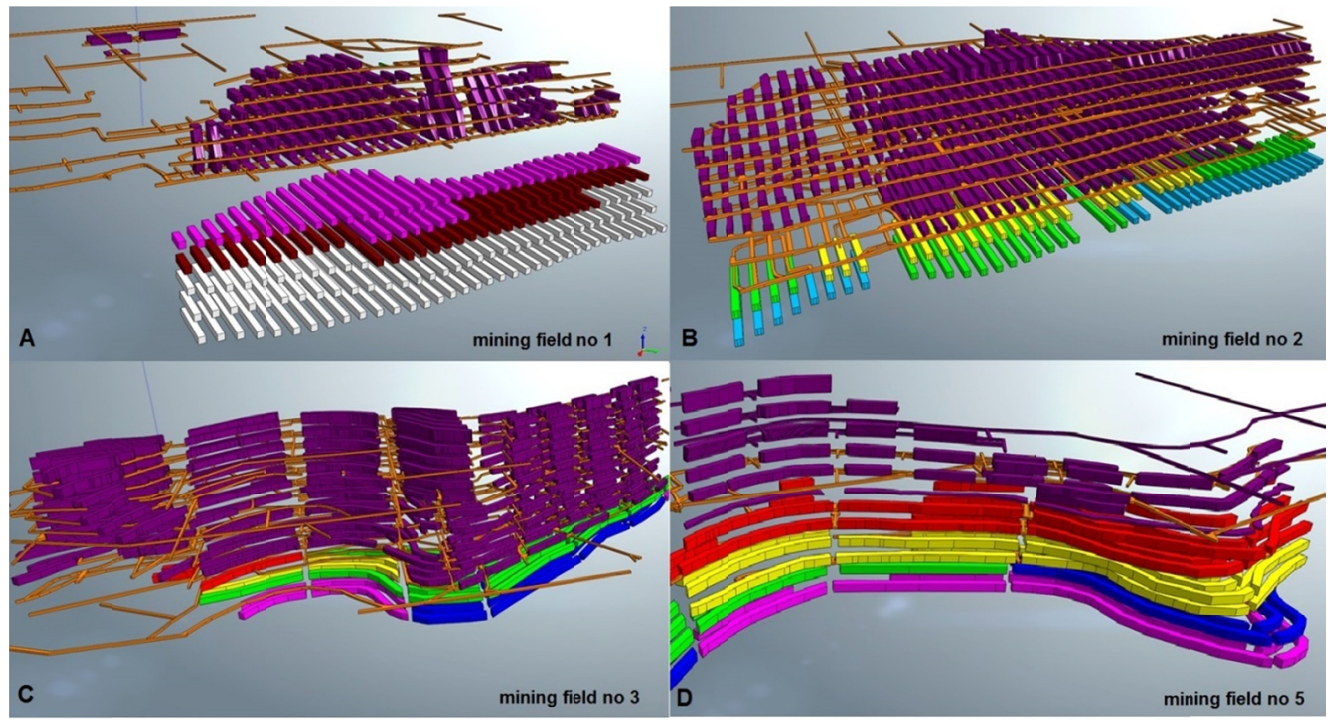

\section{Extraction periods}

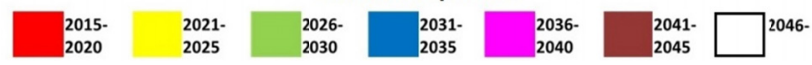

Fig. 2. The 3D models of selected mining fields in the Kłodawa salt mine: A - mining field no 1, B - mining field no 2, C-mining field no 3, D - mining field no 5. Colours are related to extraction periods

Mechanical parameters used in geomechanical analysis

\begin{tabular}{|c|c|c|c|c|}
\hline \hline Parameters & Anhydrite & Rocks & Rock salt & Carnallite \\
\hline Bulk density $\left[\mathrm{kg} / \mathrm{m}^{3}\right]$ & 2300 & 2300 & 2300 & 2300 \\
\hline Young's modulus [MPa] & 5000 & 4000 & 5000 & 4718 \\
\hline Poisson's ratio [-] & 0.30 & 0.25 & 0.40 & 0.41 \\
\hline Cohesion $[\mathrm{kPa}]$ & 3000 & 2000 & 3030 & 1685 \\
\hline Internal friction angle [ $\left.{ }^{\circ}\right]$ & 35 & 30 & 35.61 & 33.86 \\
\hline Tensile strength $[\mathrm{kPa}]$ & 2000 & 1000 & 2500 & 842.5 \\
\hline
\end{tabular}

In addition, creep parameters for rock salt and carnallite (determined in laboratory tests and calculated on the basis of the Norton law) are $n=4.85$ and $A=6.5 \cdot 10^{-46} \mathrm{~Pa}^{-4.85} \mathrm{~s}^{-1}$.

In numerical calculations, a model for elastic-plastic material with the Coulomb-Mohr failure criterion was applied for anhydrite and rocks but elastic-plastic-viscous material with the Power Law model (rheological) for rock salt and carnallite. Moreover, the boundary condition of the model were introduced and displacement in the direction perpendicular to bottom and side planes of the model was blocked. The value of the hydrostatic stress changed with the depth from zero at the surface to $28.2 \mathrm{MPa}$ at the bottom of the $3 \mathrm{D}$ model. 


\section{Results}

Results of deformation analysis were divided into two parts: assessment of the mine stability conditions in year 2014 and prediction for the year 2052 (end of rock salt extraction). Based on 3D numerical analysis, it was indicated that the overall stability conditions in the Kłodawa salt mine at the end of 2014 were stable. The state of vertical stress (in comparison to initial pre-mining stress state) was risen locally, mainly in inter-room pillars. The highest increase in vertical stress was indicated at mining level 720 (Fig. 3A) in the mining field no $2(74 \%)$ and at the mining level 475 (Fig. 3B) in mining field no 3 (71\%). Evaluation carried out for another mining fields and levels showed that the vertical stress was increased at the level of $54-61 \%$ in relation to pre-mining conditions.

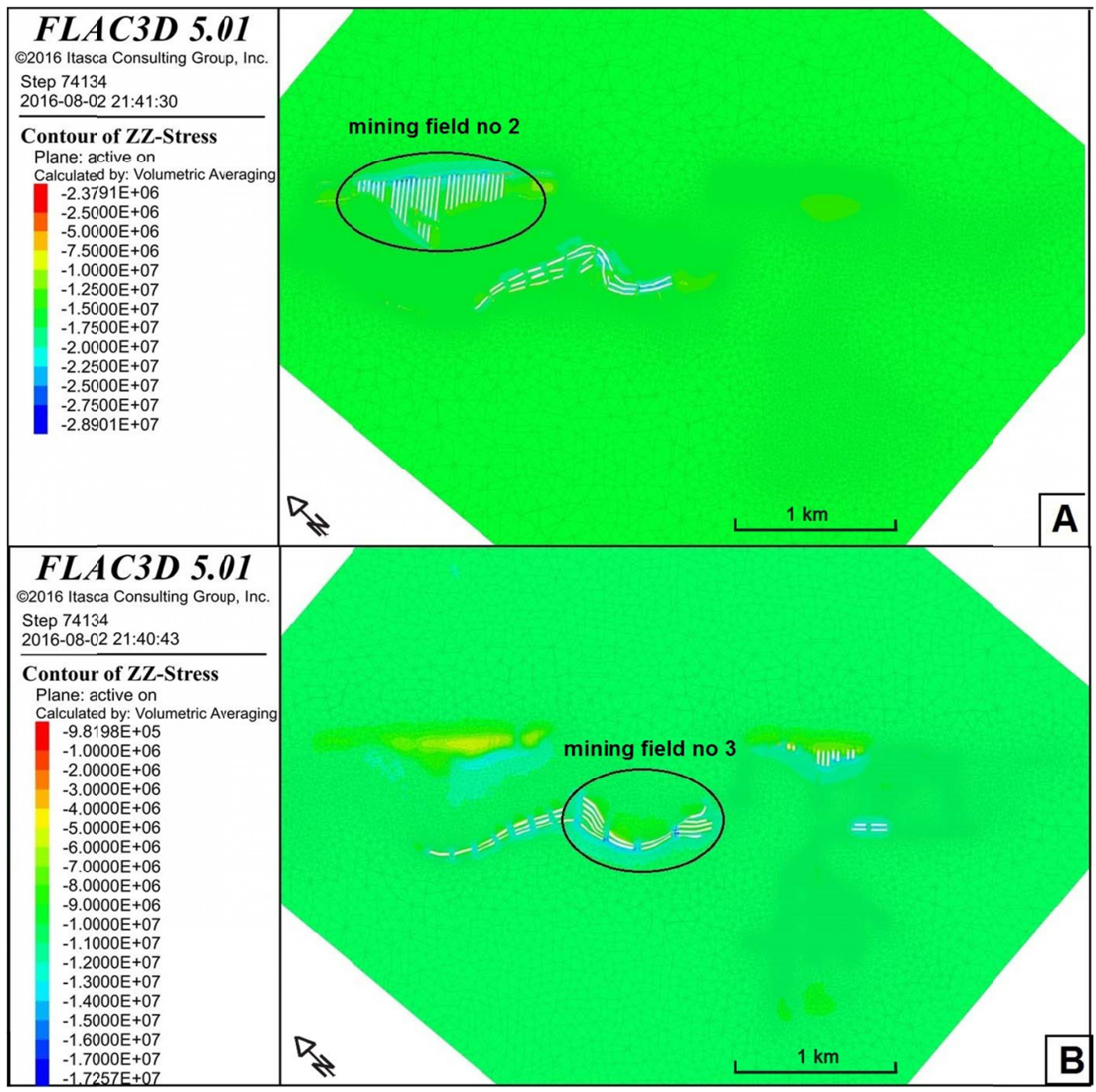

Fig. 3. The vertical stress state in 2014 at selected mining levels: A - mining level 720, mining field no 2 was circled; B - mining level 475, mining field no 3 was circled 
Results for year 2052 showed the higher level of the vertical stress then estimated for year 2014. The maximum increase were predicted at the mining level 575 (Fig. 4A) in the mining field no $6(84 \%)$ and at the mining level 810 (Fig. 4A) in the mining field no $2(86 \%)$. It is expected that for the other analysed mining levels and fields the increase in vertical stress is at the level of $52-76 \%$ in comparison to initial conditions. All these changes in vertical stress occurred locally and were associated with inter-room pillars.

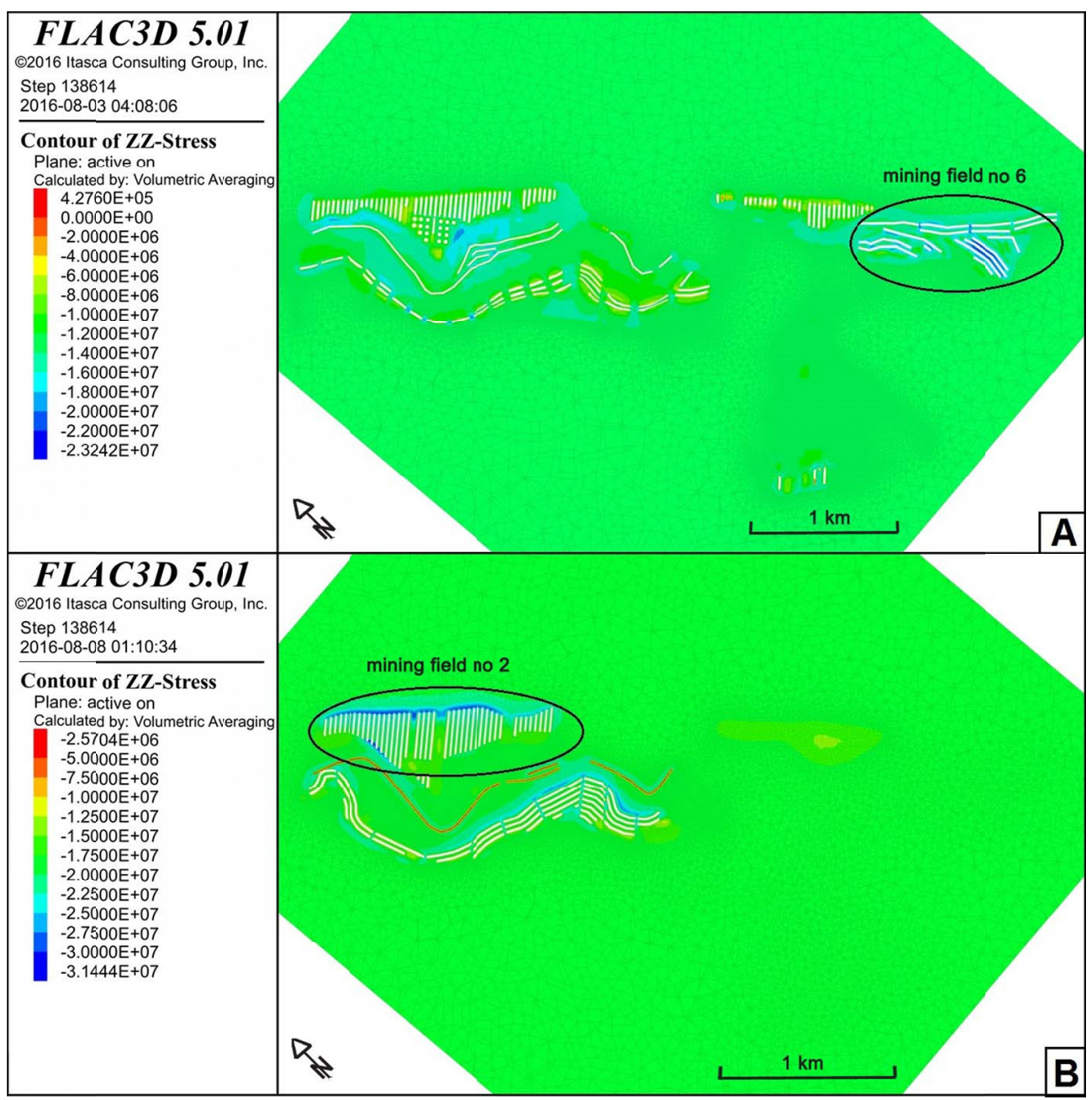

Fig. 4. The vertical stress state in 2052 at selected mining levels: A - mining level 575, mining field no 6 was circled; B - mining level 810, mining field no 2 was circled

The locally occurring increases in the vertical stress were connected mainly with intensive excavation works which in year 2014 were focused in the mining field no 2 at the mining level 475 and in year 2052 are planned at the mining level 810 as well as in the mining field 6 . How- 
ever, the vertical stress increase in inter-room pillars in the mining field no 3 (year 2014) was primarily engaged with high rooms excavated in the first years of rock salt extraction.

Analysis of the strength/stress ratio for year 2014 revealed that stability conditions in the Kłodawa mine were stable. Low strength/stress ratio (the strength/stress ratio value 1.0 implies a state close to failure) was indicated for some inter-room pillars. The low strength/stress ratio was associated mainly with inter-room pillars (which are part of module 2) in the mining field no 1 at mining levels 525, 550, 575 and 600 (Fig. 5A) as well as in central and north-west part of mining field no 2. Moreover, single inter-room pillars showed low value of the strength/stress ratio in the mining fields no 2 and 3 at mining levels 630 and 660 (Fig. 5B) as well as parts of inter-room pillars in the mining fields no 2 and 3 at the lower mining levels (690, 720 and 750) (Fig. 5B).

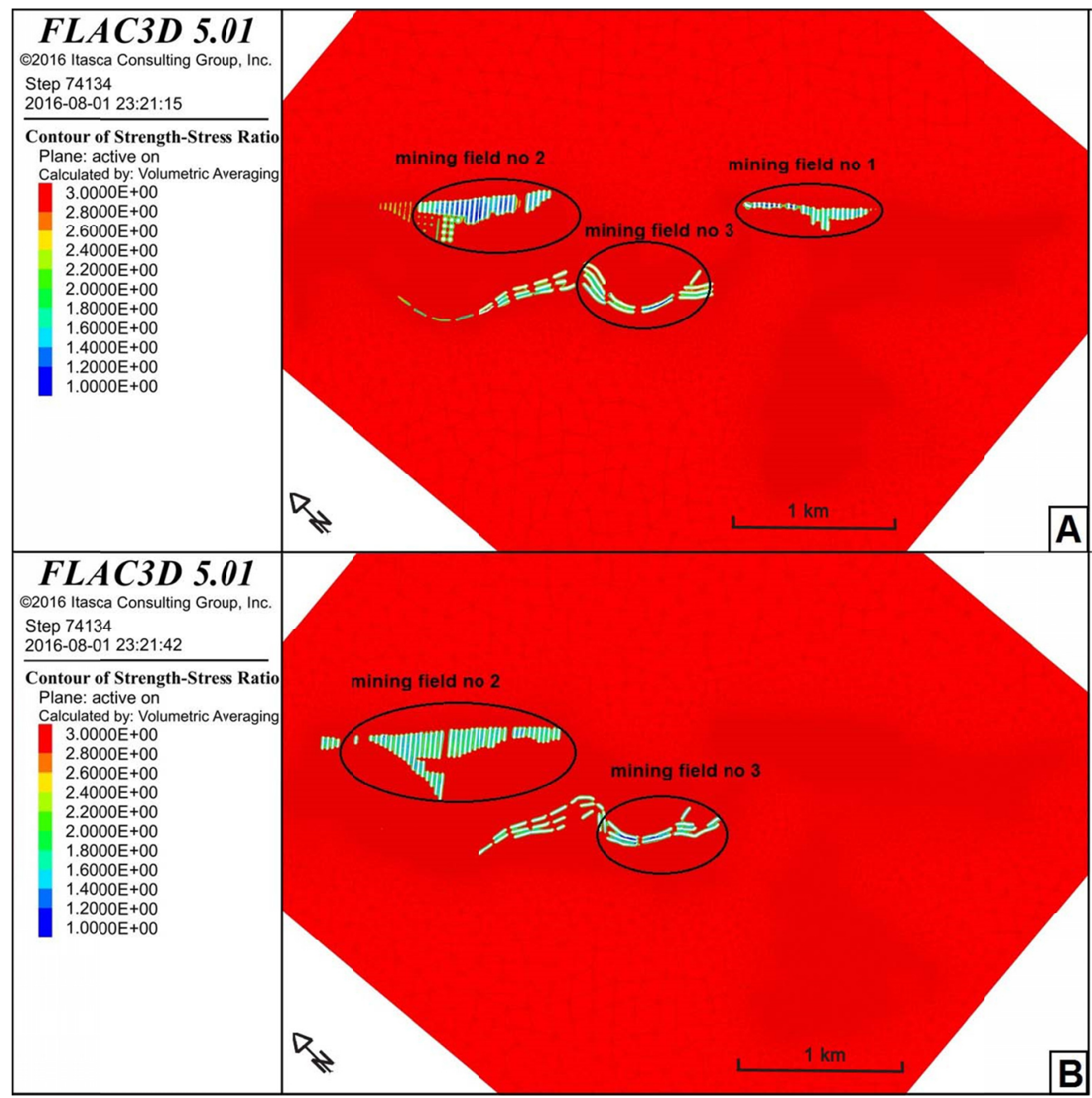

Fig. 5. The strength/stress ratio at selected mining levels in year 2014: A - at mining levels 525, B - at mining level 660 
Indicated in numerical analysis potential endangered zones were primarily connected with high rooms situated in the mining field no. 1 that had been extracted at the beginning of Kłodawa mining activity. Potentially hazardous conditions in the single inter-room pillars in mining fields no 2 and 3 are associated with complex geological structure in this area.

At the end of the rock salt extraction (year 2052), minor changes in stability conditions were predicted in comparison to the state in 2014. In mining fields no 1, 2 and 3 low value of the strength/stress ratio was associated inter-room pillars similarly to results presented for year 2014 . In addition, low strength/stress ratio was indicated for inter-room pillars in the mining field no 6 at mining levels 575 and 600 (Fig. 6A). In mining field no 7 (Fig. 6B) the low strength/stress ratio is expected locally in walls of chambers at all mining levels (from 525 to 810 ).

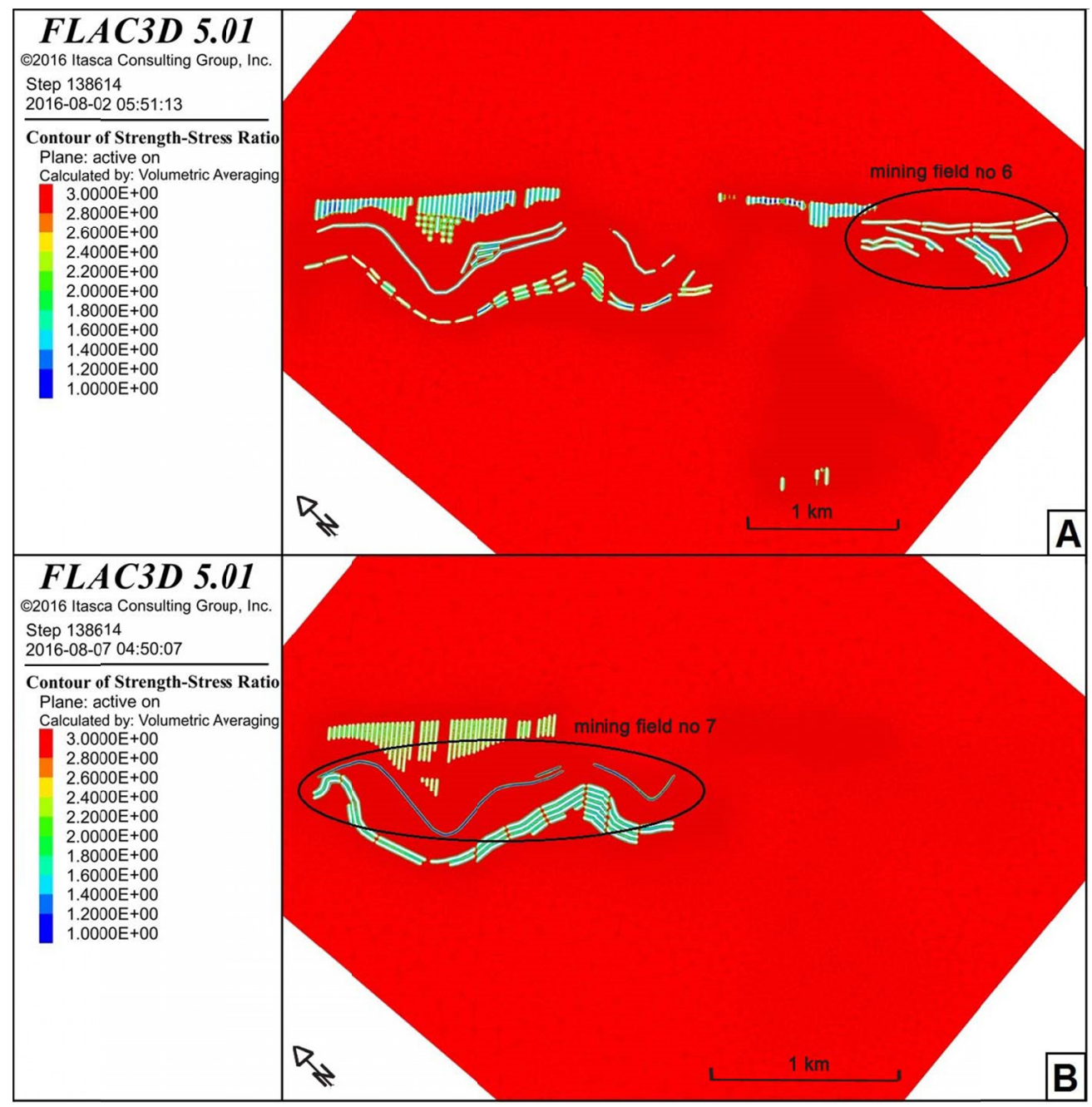

Fig. 6. The strength/stress ratio at selected mining levels in year 2052: A - at mining levels 575, mining field no 6 was circled; $\mathrm{B}$ - at mining level 780, mining field no 7 was circled 
However, it was predicted that the overall stability conditions in 2052 were stable. Potential risky zones indicated in the mining field no 7 correlate with carnallite layers which are characterised by weaker mechanical parameters than rock salt. Moreover, in the mining field no 6 intensive mining activity is planned in the last 5 years of salt extraction, consequently local changes in the stability conditions are expected.

It should be underlined that local changes in stability conditions indicated for the single mining field had no or minor impact to the mine workings included in the other mining fields. Minor influence between mining fields no 3 and 5 was indicated in numerical analysis for year 2014 (Fig. 7A) as well as influence of the mining field no 7 to the mining fields 2, 3, 5 and between mining fields 1 and 6 for year 2052 (Fig. 7B).

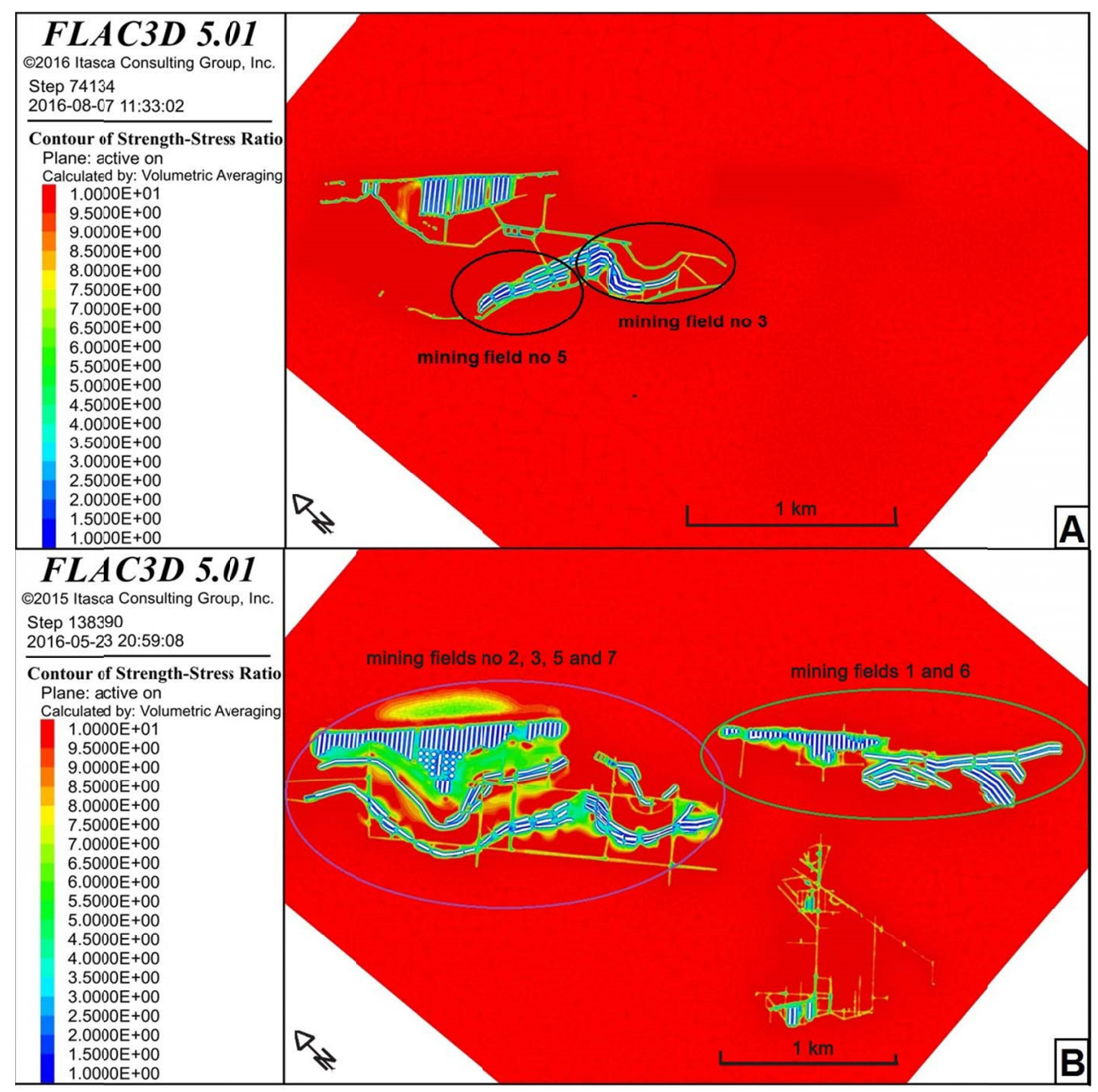

Fig. 7. The strength/stress ratio at selected mining levels: A - at mining levels 750 , mining fields no 3 and 5 were circled (year 2014); B - at mining level 600, mining fields no 2, 3, 5, 7 were circled in purple and mining fields no 1 and 6 were circled in green (year 2052) 


\section{Conclusions}

The long-term deformation analysis of the Kłodawa salt mine revealed that current stability conditions (estimated for year 2014) and future stability conditions expected for year 2052 were stable. Local disturbances indicated in the numerical analysis were connected with high chambers included in the mining field no 1 and complex geological structure in the vicinity of mine workings located in the mining fields no 2 and 3.

Moreover, numerical simulations that projected the future extraction progress showed positive performance. Planned mining works at deeper levels in all mining fields and the lowest mining levels 780 and 810 are not predicted to bring major changes in the overall stability conditions of the Kłodawa salt mine. Assessment of the stability conditions for year 2052 indicated occurrence of local weakness zones in the mining field no 7 and 6 . They are associated with intensive mining works concentrated in the mining field no 6 as well as the presence of carnallite layers in the mining field no 7.

However, all local disturbances described in the paper should be treated as potential endangered zones for which constant monitoring is recommended. In addition, continuous convergence monitoring of mine workings as well as periodic update of the 3D model in relation to exploitation progress is advisable.

It should be underlined that the 3D numerical model and deformation analysis were carried out taking into consideration the current recognition of the geological structure, mine working distribution and mechanical parameters of local rocks. Consequently, any future changes in geological and mining settings resulted from further extraction activity or geological recognition may affect presented results.

\section{References}

Andrusikiewicz W., Poborska-Młynarska K., 2012. The estimation of re-exploitation possibilities of part of reserves left in exploitation field number 2 in the ,Kłodawa“ Salt Mine on the example of the chamber KS-21/600. Geology, Geophysics and Environment 38 (1), 69-82.

Burliga S., 1995. Dessication polygons within the salt deposits of the Klodawa Salt Mine. Abstracts of XIII International Congress on Carboniferous-Permian, Kraków, Poland.

Burliga S., 1996. Kinematics within the Kłodawa salt diapir, central Poland. Geological Society Special Publications $100,11-21$.

Burliga S., 2006. Tectonic mezo- and microsctructures in Permian salt sediments in Poland - detailed indicatiors of deposits inner structure. Geological Review 54, 4, 314-315 (in Polish with English summary).

Burliga S., 2014. Heterogeneity of folding in Zechstein (Upper Permian) salt deposits in the Kłodawa Salt Structure, central Poland. Geological Quarterly 58, 3, 565-576.

Burliga S., Kolonko P., Misiek G., Czapowski G., 1995. Kłodawa salt mine. [In:] Małecka J. (ed.) Upper Rotliegend Zechstein: Terrestrial - Marine Sedimentary Succession in Polish Permian Basin: 45-54. XIII International Congress on Carboniferous-Permian, August 28-September 2, 1995, Guide to Excursion A3, Cracow, Poland (in Polish).

Burliga S., Misiek G., 1997. Kłodawa salt mine - geological structure and development of salt dome. [In:] Burliga S. (ed.) Salt Tectonics in the Kuiavian Region: 1-12. WIND-J. Wojewoda, Wrocław (in Polish).

Cała M., Stopkowicz A., Kowalski M., Blajer M., Cyran K., 2016. Stability analysis of underground mining openings with complex geometry. Studia Geotechnica et Mechanica 38, 1, 25-32.

Chwałek J., 2010. Salt Mine "Kłodawa" - historical overview of the terms of the mine construction and development. Zagożdżon P.P. \& Madziarz M. (eds.) History of mining - part of European cultural heritage, Wrocław 2010 (in Polish with English summary). 
Dadlez R., Marek S., 1974. General outline of the tectonics of the Zechstein-Mesozoic complex in central and northwestern Poland. Bulletin of Polish Geological Institute 274, 11-140 (in Polish with English summary).

Dadlez R., Narkiewicz M., Stephenson R.A., Visser M.T.M., van Wees J.D., 1995. Tectonic evolution of the Mid-Polish Trough: modelling implications and significance for central European geology. Tectonophysics 252, 179-195.

Dadlez R., 2003. Mesozoic thickness pattern in the Mid-Polish Trough. Geological Quarterly 47, 3, 223-240.

d'Obyrn K., Hydzik-Wiśniewska J., 2013. Selected aspects of numerical modelling of the salt rock mass: the case of the “Wieliczka” salt mine. Archives of Mining Sciences 58, 1, 73-88.

Garlicki A., Szybist A., 1986. Saline deposits of Polish Zechstein with potash salts. Gospodarka Surowcami Mineralnymi 2, 389-404 (in Polish with English summary).

Heusermann S., Vogel P, Eickemeier R., Nipp H.K., 2012. Analysis of the integrity of the geological barrier in the Gorleben salt formation. [In:] Bérest P., Ghoreychi M., Hadj-Hassen F., Tijani M. (eds.) Mechanical Behaviour of Salt VII.

Jing L., 2003. A reviewof techniques, advances and outstanding issues in numerical modelling for rock mechanics and rock engineering. International Journal of Rock Mechanics \& Mining Sciences 40, 283-353.

Jing L., Hudson J.A., 2002. Numerical methods in rock mechanics. International Journal of Rock Mechanics \& Mining Sciences 39, 409-427.

Krzywiec P., 2004. Triassic evolution of the Kłodawa salt structure: basement-controlled salt tectonics within the Mid-Polish Trough (Central Poland). Geological Quarterly 48, 2, 123-134.

Krzywiec P., 2006. Triassic - Jurassic evolution of the Pomeranian segment of the Mid-Polish Trough - basement tectonics and sedimentary patterns. Geological Quarterly 51, 1, 139-150.

Mortazavi A., Hassani F.P., Shabani M., 2009. A numerical investigation of fock pilar failure mechanism in underground openings. Computers and Geotechnics 36, 691-697.

Poborski J., 1971. Revolution in view for tectonics of Polish salt dome in Kujawy region. Conference Proceedings. Inowrocław-Kłodawa, 10-12 November 1971, AGH, Cracow (in Polish).

Sadowski A., Poborska-Młynarska K., Czapowski G., 2007. The possibilities of reuse and utilization of underground voids in Kłodawa salt mine. Conference Proceedings "Natural hazards in Mining", Ślesin, 4-6 June 2007. The Mineral and Energy Economy Research Institute of the Polish Academy of Sciences, Cracow (in Polish).

Swift G.M., Redish D.J., 2005. Underground excavations in rock salt. Geotechnical and Geological Engineering 23, $1,17-42$.

Szybist A., 1995. Geological cross-section through Kłodawa Salt Dome. Archive of the Department of Geology and Mining Faculty of Geology, Geophysics and Environmental Protection, AGH University of Science and Technology, Cracow (in Polish).

Tarka R., 1992. Tectonics of some salt deposits in Poland based on mesostructural analysis. Prace Państwowego Instytutu Geologicznego, 137 (in Polish with English summary).

Toboła T., 2016. Inclusions in anhydrite crystals from blue halite veins in the Kłodawa Salt Dome (Zechstein, Poland). Geological Quarterly 60, 3, 572-585.

Werner Z., Poborski J., Orska J., Bakowski J., 1960. A geological and mining outline of the Klodawa salt deposits. Prace Instytutu Geologicznego 30. 467-494 (in Polish with English summary).

Zhang G., Wu Y., Wang L., Zhang K., Daemen J.J.K., Liu W., 2015. Time-dependent subsidence prediction model and influence factor analysis for underground gas storages in bedded salt formations. Engineering Geology 187, $156-169$. 